\title{
USE OF ANKLE BLOCK AS ALTERNATIVE TO SPINAL ANAESTHESIA FOR SURGERIES IN DIABETIC FOOT PATIENTS
}

Pradeep Kumar. S.

1. Assistant Professor. Department of General Surgery, Dr. B. R. Ambedkar Medical College, Bangalore.

\section{CORRESPONDING AUTHOR:}

Dr. Pradeep Kumar. S,

No.108, Shivashakthi Nilaya,

$5^{\text {th }}$ cross, $11^{\text {th }}$ main,

B .T .S Layout, Siddedahalli, Bangalore-560073

E-mail: dr.pradeep_k20@yahoo.com

Ph: 0091919902349960

INTRODUCTION: Diabetes is one of most common co-morbid conditions in our day to day practice. With increasing lifespan, complications like diabetic neuropathy, retinopathy, and diabetic foot are increasing. The last mentioned forms a considerable part of surgical practice; these patients are difficult to manage as they are not fit for any type of anaesthesia as hypertension and cardiac diseases co-exist. It is in these patients that local anaesthesia where ever possible plays an important role. AIM OF STUDY: To study efficacy of ankle block peroperatively and postoperatively in surgeries $2,3,5$ for diabetic foot. MATERIALS AND METHODS: 15 patients in age group 40-80years admitted in Dr. B R Ambedkar medical college from Jan 2009-Jan 2010 with diabetic foot were studied of which 9 were males and 6 were females. INCLUSION CRITERIA: Diabetic patients below grade $4{ }^{1}$; Those willing for ankle block ; Those who are unfit for spinal anaesthesia EXCLUSION CRITERIA: Those above grade $4^{1}$ and those not willing for ankle block.

KEY WORDS: ankle block,spinal anaesthesia,diabetic foot

TECHNIQUE OF ANKLE BLOCK: Surgical parts painted and draped, 10ML of 2\% Xylocaine diluted to 20ML with distilled water and 5ML is injected medial to dorsalis pedis pulsations; $5 \mathrm{ml}$ below medial malleolus along direction of flexor retinaculum; $5 \mathrm{ml}$ above medial malleolus around long saphenous vein and $5 \mathrm{ml}$ below lateral malleolus

Our study included 15 patients, 9 of them (60\%) were males (Tables 1 and 3); majority $40 \%$ were in age group 51-60(Table 2); out of 15 patients, $12(80 \%)$ underwent debridement ${ }^{5}$, $2(13.3 \%)$ had toe disarticulation and 1 had forefoot amputation ${ }^{4}$ (Table 4); 14(93.3\%) patients tolerated procedure well,1 patient complained of pain and required sedation to complete procedure(Table 5).

Among co-morbid conditions, 6 patients (40\%) had hypertension and cardiac disease;5 patients(33.3\%) had hypertension alone(Table 6).

DISCUSSION: With increasing lifespan, complications like diabetic neuropathy, retinopathy, and diabetic foot are increasing. The last mentioned forms a considerable part of surgical practice; these patients are difficult to manage as they are not fit for any type of anaesthesia as hypertension and cardiac diseases co-exist. It is in these patients that local anaesthesia where ever possible plays an important role

Spinal anaesthesia and General anaesthesia requires careful assessment and preparation for eg. in diabetes due to preoperative fasting, there is need for monitoring sugar 
control, furthermore other co-morbid illness like obesity, hypertension, cardiac problems are more in diabetics and hypotension induced by spinal anaesthesia could be detrimental. Further the stress of general anaesthesia can aggravate cardiac problems. Regional anaesthetic blocks are safe and effective methods that do not produce any serious hemodynamic disturbances, therefore local blocks are always safer.

CONCLUSION: Even though spinal anaesthesia is used routinely for diabetic foot patients, ankle block can be used effectively in certain patients especially those with co-morbid diseases like hypertension, obesity and cardiac disease.

\section{REFERENCES:}

1. Shor NA [Clinical classification of diabetic foot syndrome]. [English Abstract, Journal Article] Klin Khir 2011 Sep; (9):55-7.

2. Jirkovská A [Adherence to the international guidelines on the treatment of diabetic leg syndrome]. Vnitr Lek 2011 Nov; 57(11):908-12.

3. López Herranz M, Bas Caro P, Carabantes Alarcón D, et al.[Therapeutic uses of orthopodiatry in the diabetic foot]. [English Abstract, JournalArticle] Rev Enferm 2011 Oct; 34(10): 30-9.

4. Tosun B, Buluc L, Gok U, et al.Boyd amputation in adults. [Journal Article] .Foot Ankle Int 2011 Nov; 32(11):1063-8

5. Gordon KA, Lebrun EA, Tomic-Canic M, et al. The role of surgical debridement in healing of diabetic . Foot ulcers. [Journal Article, Review] Skinmed 2012 Jan -Feb; 1

Table 1-Patient characteristics

\begin{tabular}{|c|c|c|c|c|c|}
\hline Serial no. & Age & Sex & Limb affected & Co-morbid illness & Procedure undergone \\
\hline 1 & 47 & $\mathrm{M}$ & $\mathrm{R}$ & $\mathrm{O}, \mathrm{H}, \mathrm{C}$ & $\mathrm{D}$ \\
\hline 2 & 54 & $\mathrm{~F}$ & $\mathrm{~L}$ & $\mathrm{H}$ & $\mathrm{D}$ \\
\hline 3 & 52 & $\mathrm{M}$ & $\mathrm{L}$ & $0, \mathrm{H}$ & $\bar{D}$ \\
\hline 4 & 77 & $\mathrm{M}$ & $\mathrm{R}$ & $\mathrm{H}$ & $\mathrm{D}$ \\
\hline 5 & 63 & M & $\mathrm{L}$ & $\mathrm{H}, \mathrm{C}$ & $\mathrm{D}$ \\
\hline 6 & 74 & $\mathrm{~F}$ & $\mathrm{R}$ & $0, \mathrm{H}$ & $\mathrm{T}$ \\
\hline 7 & 79 & $\mathrm{~F}$ & $\mathrm{~L}$ & $\mathrm{H}$ & $\mathrm{D}$ \\
\hline 8 & 57 & $\mathrm{M}$ & $\mathrm{R}$ & $\mathrm{H}, \mathrm{C}$ & $\mathrm{D}$ \\
\hline 9 & 65 & $\mathrm{~F}$ & $\mathrm{R}$ & $\mathrm{H}, \mathrm{C}$ & $\mathrm{T}$ \\
\hline 10 & 59 & $\mathrm{M}$ & $\mathrm{L}$ & $0, \mathrm{H}$ & $\mathrm{D}$ \\
\hline 11 & 62 & $\mathrm{M}$ & $\mathrm{R}$ & $\mathrm{H}$ & FA \\
\hline 12 & 60 & $\mathrm{~F}$ & $\mathrm{R}$ & $\mathrm{H}$ & $\mathrm{D}$ \\
\hline 13 & 61 & $\mathrm{M}$ & $\mathrm{L}$ & $\mathrm{H}, \mathrm{C}$ & $\mathrm{D}$ \\
\hline 14 & 51 & $\mathrm{M}$ & $\mathrm{L}$ & $\mathrm{H}, \mathrm{C}$ & $\mathrm{D}$ \\
\hline 15 & 50 & $\mathrm{~F}$ & $\mathrm{R}$ & $\mathrm{H}, \mathrm{C}$ & $\mathrm{D}$ \\
\hline INDEX & M-MALE & F-FEMALE & R-RIGHT & L-LEFT & O-OBESITY \\
\hline \multicolumn{6}{|c|}{$\begin{array}{l}\text { H-HYPERTENSION C-CARDIAC DISEASE D-DEBRIDEMENT T-TOE DISARTICULATION } \\
\text { FA-FOREFOOT AMPUTATION }\end{array}$} \\
\hline
\end{tabular}


Table 2 -Distribution of patients according to age of the patients

\begin{tabular}{|c|c|c|}
\hline Age Group & Number of patients(\%) & \multirow{6}{*}{ Mean age group $=60.7 \mathrm{yrs}, \mathrm{SD}= \pm 9.38$} \\
\hline $41-50$ & $2(13.3)$ & \\
\hline $51-60$ & $6(40.0)$ & \\
\hline $61-70$ & $4(26.7)$ & \\
\hline $71-80$ & $3(20.0)$ & \\
\hline TOTAL & 15 & \\
\hline
\end{tabular}

Table 3- Distribution of patients according to sex of the patients

\begin{tabular}{|c|c|}
\hline Sex of the patient & Number of patients \\
\hline Male & $9(60.0 \%)$ \\
\hline Female & $6(40.0 \%)$ \\
\hline Total & 15 \\
\hline
\end{tabular}

Table 4-Distribution of patients according to the type of surgery

\begin{tabular}{|c|c|}
\hline Type of surgery & Number of patients \\
\hline Debridement & $12(80 \%)$ \\
\hline Toe disarticulation & $2(13.3 \%)$ \\
\hline Fore foot amputation & $1(6.7 \%)$ \\
\hline Total & 15 \\
\hline
\end{tabular}

Table 5-Distribution of patients according to patient compliance

\begin{tabular}{|c|c|}
\hline $\begin{array}{c}\text { Type of patient } \\
\text { compliance }\end{array}$ & Number of patients \\
\hline Tolerated well & $14(93.3 \%)$ \\
\hline Complained of pain & $1(6.7 \%)$ \\
\hline Total & 15 \\
\hline
\end{tabular}

Table 6-Distribution of patients according to their co-morbidity status

\begin{tabular}{|c|c|}
\hline Co-mobidity status & Number of patients (\%) \\
\hline Hypertension & $5(33.3)$ \\
\hline Hypertension\&cardic disease & $6(40.0)$ \\
\hline Hypertension \&obesity & $3(20.0)$ \\
\hline $\begin{array}{c}\text { Hypertension,obesity\& } \\
\text { cardiac disease }\end{array}$ & $1(6.7)$ \\
\hline TOTAL & 15 \\
\hline
\end{tabular}




\section{ORIGINAL ARTICLE}
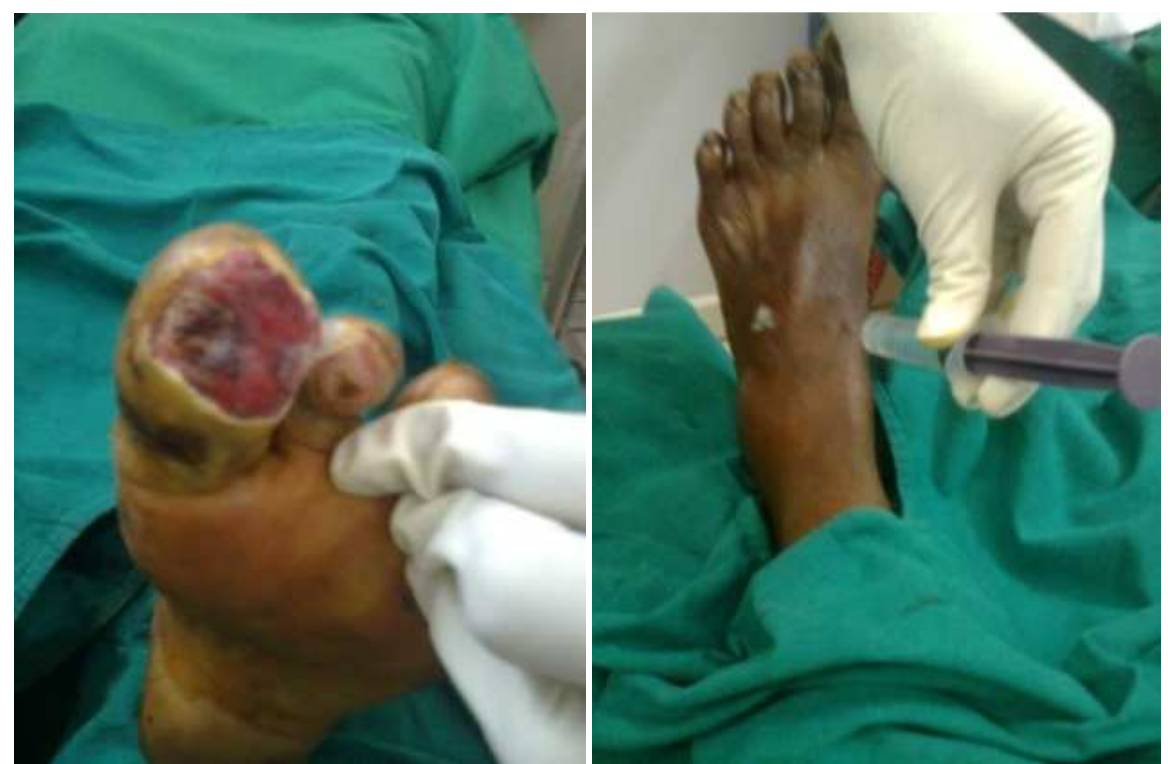

Fig 1:Diabetic foot ulcer

Fig 2: 5ML is injected medial to medial To pedis pulsations
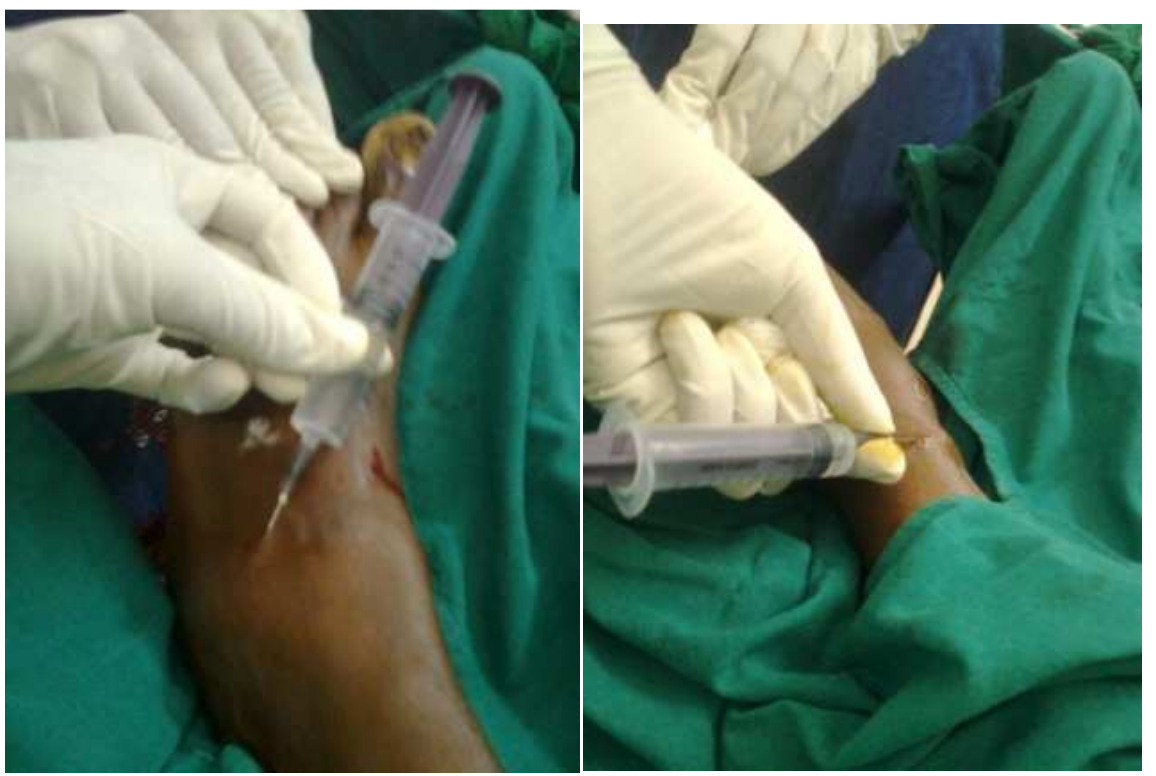

Fig 3: $5 \mathrm{ml}$ below lateral malleolus

Fig 4: $5 \mathrm{ml}$ above medial malleolus dorsalis around long saphenous vein 